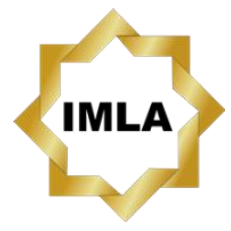

Available online:

http://journal.imla.or.id/index.php/arabi

Arabi : Journal of Arabic Studies, 5 (1), 2020, 11-24

DOI: http://dx.doi.org/10.24865/ajas.v5i1.180

\title{
CULTURAL VALUES OF WOMEN AND MARRIAGE IN AL-'ARABIYYAH BAYNA YADAIK AND AL-KITAB FI TA'ALLUM AL-'ARABIYYAH
}

\author{
Fatwa Arifah', Emzir', Sukron Kamil ${ }^{2}$ \\ 'Universitas Negeri Jakarta, Indonesia \\ ${ }^{2}$ Universitas Islam Negeri Syarif Hidayatullah Jakarta, Indonesia \\ E-mail : fatwa.arifah@unj.ac.id
}

\begin{abstract}
The aim of this study is to find deep information about cultural values contained in alKitab fi Ta'allum al-'Arabiyyah and al-'Arabiyyah bayna Yadaik related to women and marriage. This study used a qualitative approach with the content analysis method by Norman Fairclough's Critical Discourse Analysis which is limited to the linguistic aspect. The text describes the problems faced by women regarding the culture of marriage and reveals cultural values related to the role of women in society and their position in marriage. The result of this study confirmed that al-Kitab fi Ta'allum al'Arabiyyah and al-'Arabiyyah bayna Yadaik represent women and their position in marriage and society with a multi-perspective way. This study is important to provide critical thinking about women's issues and marriage in Arabic language teaching. Furthermore, the student and teacher will have an awareness and understanding of cultural differences to increase their ability to communicate with Arab society.
\end{abstract}

Keywords: cultural values, textbook, woman, Arabic language

\begin{abstract}
Abstrak
Tujuan penelitian ini adalah menemukan informasi mendalam tentang nilai-nilai budaya yang terkandung dalam al-Kitab fi Ta'allum al-'Arabiyyah dan al-'Arabiyyah bayna Yadaik terkait dengan wanita dan pernikahan. Penelitian ini menggunakan pendekatan kualitatif dengan metode analisis isi dengan model Analisis Wacana Kritis oleh Norman Fairclough yang dibatasi pada aspek linguistik. Teks-teks dalam kedua buku tersebut menjelaskan masalah yang dihadapi oleh wanita terkait budaya pernikahan dan mengungkapkan nilai-nilai budaya yang terkait dengan peran wanita dalam masyarakat dan posisi mereka dalam pernikahan. Hasil penelitian ini menegaskan bahwa al-Kitab fi Ta'allum al-'Arabiyyah dan al-'Arabiyyah bayna Yadaik mewakili perempuan dan posisi mereka dalam perkawinan dan masyarakat dengan cara multi-perspektif. Ini penting untuk memberikan pemikiran kritis tentang isu-isu perempuan dan pernikahan dalam pengajaran bahasa Arab. Jadi, siswa dan guru akan memiliki kesadaran dan pemahaman tentang perbedaan budaya untuk meningkatkan kemampuan mereka berkomunikasi dengan masyarakat Arab.
\end{abstract}

Kata Kunci: nilai budaya, buku teks, wanita, bahasa Arab 


\section{Arabi : Journal of Arabic Studies}

\section{Introduction}

Learning Arabic as other foreign language learning is inseparable from cultural learning. Cultural learning can be found in textbooks used in language learning. Aisah Hasmam and Nik Mohd Rahimi stated that textbooks are the main source in the process of Arabic learning and, therefore, the materials in a textbook consisting of text that need to be examined more deeply. Hasmam and Rahimi mention that there are seven types of text in textbooks: conversation (hiwar), description, poetry, explanations, narrative, procedures, and retelling. Then Hasmam and Rahimi (2010) added that each text in the student textbook tends to be interpreted differently. There are two ways of interpreting the text: separate interpretation of the text and interpretation of the text in combination.

Mahmoud Abdalla (2006) said that the development of Arabic for non-Arabic textbooks can be seen through several textbooks such as Modern Standard Arabic (MSA) published in 1971, Elementary Modern Standard Arabic (EMSA) published in 1975, al-Kitab al-Asasi published in 1993, and al-Kitab fi Ta'allum al-'Arabiyyah published in 1995. Khairi Abu Syairi (2013) said that Arabic textbooks used in Indonesian schools are textbooks that are mostly imported from outside (textbooks published from the middle east). In addition, Arman Husni (2010) that Arabic textbooks in Indonesia were minimal in the creation and tended to be monotonous.

Make Orr (2014) said that ideological influences in language learning can be analyzed through texts used as teaching material. In addition, Orr also emphasized that ideology in language learning can be put forward using the theory of critical discourse analysis (CDA) by applying it in studying textbooks. O'Dwyer argues that each discourse contains ideology. Ideology in language learning can also be found through the theory of cultural awareness as stated by Wenunger and Kiss, the context and understanding of ideology are not only a structure of political domination but also a cultural belief manifested in the form of practices and cultural material. Likewise, Taki argued that to build critical language awareness in language learning is not enough just to teach grammar or language structure. However, language learning with a critical language awareness approach emphasizes the understanding of communication systems to share ideas and ways to control a person and influence one's thoughts and actions through language.

Gender is a kind of ideology which is still a matter in language learning that needs to be studied. This can be seen from the results of previous researches. Mitra Baghdadi and Ali Rezaei, studying gender representation contained in English and Arabic textbooks in Iran, found that in the two textbooks, male has more representation that female. In addition, Dordi Nejad and Bakshi (2014) emphasize that there is a close relationship between language and power, where every word put forward by the owner of power or authority is assumed to be a truth. This also relates to the tendency of students who consider all information contained in textbooks to be true, undoubted, and not to be questioned (2006).

Gender in this study is a cultural concept that seeks to make a difference in terms of roles, behavior, and mentality between men and women (Tierney, 1999, h.563). Hilary M Lips (2008) defines it with the term "culturally expectations" associated with masculinity and femininity. Mansour Fakih (2013) and Zaitunah Subhan (2018) define gender as a term that refers to the inherent traits of men and women who are socially and culturally constructed. Gender also means a difference that is not biological and not something that is God's nature. Gender is a behavioral difference between men and women that are formed through social and cultural processes that last for generations (Nugroho, 2008, h.3 and Umar, 2001, h.33).

It can be concluded that textbooks have an important role in learning. Textbooks play a role in providing information about the culture of the speech community. Stephen Billy Olajide (2010) states that culture is not monolithic, each textbook author has a different style and point of view in writing culture in the textbook he writes. Therefore, this study assumes that there are differences in culture that are displayed in Arabic textbooks for non-Arabic students. 
This study is important because of the needs for understanding gender, especially about women marriage and their role in society, in learning Arabic. Learning Arabic in Indonesia is inseparable from the development of Islamic education. It is seen that from the history of the development of Islamic education in Indonesia, that mastery of Arabic has become the standard for learning religious books. However, Arabic language learning in Indonesia in general is still focused on the goal of religious understanding without being followed by the development of an understanding of culture and communication competencies.

The research on woman gender in textbooks is a study that is mostly done to reveal gender issues and aims to provide an understanding of gender awareness in education. This can be known from several studies that have been carried out as follows:

Hayat Aoumer (2014) in gender representations in three school textbooks: A feminist critical discourse analysis conducted research on the representation of men and women depicted in three textbooks at the elementary school level in Algeria. Aoumer emphasized in his research that although the government had promoted "gender equality", the representation of men and women in textbooks was still a problem. Textbooks still illustrate traditional stereotypes and perspectives on gender issues.

Siti Azisah (2017) in the Gender Representation in English Textbooks of 2013 Curriculum in an Islamic Junior High School in South Sulawesi Indonesia stated that textbooks play a role in transmitting values, behaviors, norms, and perspectives on gender.

Mitra Baghdadi and Ali Rezaei (2015) in the Gender Representation in English and Arabic Foreign Language Textbooks in Iran: A Comparative Approach stated that in all the gender analysis criteria conducted in his research it was found that male representation was more numerous than women. Men become the "central point" in most sentences, the main figure in sentences and images.

Kamel Ali Suleiman Ottom (2014) in the Image of Women in the Arabic Language Textbook for the Primary Second Grade in Jordan said that in his research found 41 roles for women while 74 roles for men. The role of women who appear in textbooks is mostly as mothers, daughters, students, teachers, and friends. In addition, women also appear once as researchers, farmers, painters, and directors.

Gender studies in textbooks also relate to the influence of ideology in the learning of foreign languages. this can be known through research conducted by Farhad Ghorban Dordi Nejad and Hooman Eshagh Bakhshi in The Role of Language Ideology in Language Teaching states that language is not only limited to learning sounds, vocabulary, and grammar. However, foreign language learning is also a socio-political tool that is influenced by a certain power (Tollefson and Yamagami, 2013). This causes the learning of foreign languages can be used as a tool to strengthen the status and power of a group, as well as a tool to achieve their goals, spread ideas, and influence other community groups. Anthony J. Liddicoat and Kerry Taylor (2015) stressed the importance of foreign language instructors' understanding of the concept of language ideology, this is for them to be able to apply in their learning, to increase awareness for foreign language learners and students can know and understand implicit values in language use.

In addition, Misako Tajima (2010) in the ideological messages embedded in the EFL textbook states that the Columbus 21 English Course textbook represents American and Japanese culture. However, in the presented material, there are stereotypes that describe Japanese characters weaker than American characters. Tajima emphasized that the study of textbooks must also consider how the textbooks are applied in the classroom. Thus, the teaching and learning process also has an important role in processing the textbook. Misako's research corroborated by Ryuko Kubota's research in Ideologies of English in Japan stated that learning English concluded cultural and linguistic stereotypes towards Japanese society. Regarding stereotypes in foreign language learning, Lucia Buttaro in Stereotypes in a Foreign Language Classroom - Modifying Negative Attitudes to Enhance Foreign Language Learning states that teachers have a role in providing 


\section{Arabi : Journal of Arabic Studies}

information to students and plays an important role in shaping student attitudes to have a sense of tolerance and open to culture other. To avoid stereotypes in learning foreign languages, instructors are advised to adopt some teaching material and discuss it with students. Regarding this, Buttaro revealed the concept ideas about teaching the world about the world to be able to create better foreign language learning so that intercultural understanding can be realized.

Based on the previous researches, this study has something in common, which is a study on textbooks in terms of gender representation that is displayed in textbooks. However, it differs in term of analyzing the gender forms contained in the discourse of al-Kitab fi Ta'allum al'Arabiyyah volume 1, 2, 3 second edition and al-'Arabiyyah Bayna Yadaik volume 1, 2, 3 third edition. The form of gender examined in this study identified gender biases which consisted of women's subordination, cultural constructs and gender roles.

Researchers found minimal studies regarding the analysis of gender-oriented textbooks. Therefore, this research tries to fill this gap. This research is also different from previous studies in terms of the methods used. This study uses the theory of critical discourse analysis by Norman Fairclough. The novelty of this study lies on the analysis at the level of discourse, not merely in the form of content analysis. Critical discourse analysis examines the themes contained in the textbook al-Kitab fi Ta'allum al-'Arabiyyah and al-'Arabiyyah Bayna Yadaik which contain gender. Gender analysis in the two textbooks is to critically examine gender issues such as cultural values of women and marriage.

\section{Method}

The focus of this study is to find in-depth information about woman and marriage in Arabic textbook al-Kitab fi Ta'allum al-'Arabiyyah dan al-'Arabiyyah bayna Yadaik. Al-Kitab fi Ta'allum al-'Arabiyyah was written by Kristen Brustad, Mahmoud al-Batal and Abbas al-Tonsi. Al-Kitab fi Ta'allum al-'Arabiyyah was published by Georgetown University Press. The first print was published in August 1995, the second in September 2004, and the third in 2013. Meanwhile, al-'Arabiyyah bayna Yadaik was written by 'Abd ar-Rahman Ibrahim al-Fauzan, Muhammad abd al-khaliq Muhammad Fadl and al-Mukhtar at-Tahir Husain. This textbook is published by Arabic for All, Riyadh, Saudi Arabia. The first production of al-'Arabiyyah bayna Yadaik became known in 2003 and the second print was published in 2014.

This study used a qualitative approach with the content analysis method based on Norman Fairclough's Critical Discourse Analysis. In addition, this study also used a sociological approach. This was based on Fairclough's view which states that discourse causes interrelated relations between social structure and discourse production processes.

The content analysis method used a deductive procedure in which the category or label has been established before analyzing the data. Categories or labels are based on theory of critical discourse analysis by Norman Fairclough. Then, the categories are 1) linguistic aspects; 2) aspects of discourse practice, and 3) sociocultural aspects.

Norman Fairclough developed a model of discourse analysis by examining discourse to social and cultural aspects and emphasizing the use of language that carries certain ideological values. Fairclough uses discourse to show the use of language as a social practice. The three dimensions that are the focus of the CDA Fairclough model are text, discourse practice and sociocultural practice (Darma, 2009, 89).

First, text analysis based on the Fairclough CDA model examines the linguistic order, namely the aspects of vocabulary, semantics, and grammar, and coherence and cohesiveness (Baghdadi and Rezaei, 2015). These elements are analyzed to be able to express the problem as follows: 1) ideational, namely to express the ideological content contained in the text. 2) Relations that refer to the analysis of the relationship between the reader and the author, how a message is conveyed (in a formal or informal way). 3) Identity that refers to the construction of the identity 
of the writer and reader, and how personal and identity are conveyed in a discourse (Fairclough, 1992).

Second, analysis of discourse practice is an analysis of dimensions related to the process of production and consumption of text. Fairclough divides discourse practices into text production (such as the media) and text consumption (in the public or society). Several factors can influence text production, namely 1) individual journalists or writers; individual aspects of a journalist or writer can determine how an event is reported. Among the influential factors is the background or origin of the journalist/writer, gender, education level, cultural and demographic background, religious orientation, political party preferences, and others; 2) organizational structure (teamwork); and 3) work practices or news reporting routines.

Third, sociocultural practice analysis is an analysis of dimensions related to the context of the situation, institutions, culture and politics. Socio-cultural practices illustrate the influence of power or power in society in interpreting and spreading the dominant ideology to the community. Fairclough divides the analysis of sociocultural practices into three levels of analysis, namely: 1) a situational level, the text is produced in a certain condition that causes a text to be different from the other texts. If discourse is understood as an action, then the action is a response to a particular social situation or context; 2) an institutional level. Institutional level analyzes the influence of organizational institutions in the practice of discourse production. The organization can come from internal media or external power/power outside the media. The factors that influence this institutional level are media and political economy; 3) a social level. The discourse that appears in the media is determined by social change. This social aspect includes macro aspects such as political systems, economic systems, and cultural systems of society as a whole. Whereas, the situational level only analyzes the micro aspects in the form of time or atmosphere and the context of events when the text is made Fairclough (1992) and Eriyanto (2008).

\section{Result and Discussion}

This study found that al-Kitab fi Ta'allum al-'Arabiyyah contains some text related to woman and marriage as following: 1) Bint Ismuha Tuffahah, 2) Zawaj al-Jayl al-Jadid, 3) al-Bint li ibn 'Ammiha, 4) Tatawwur bani al-Usrah al-'Arabiyyah, 5) al-Jami' Yufaddilunaha Khadi 'ah. Some texts in al-'Arabiyyah bayna Yadaik related to woman and marriage are: 1) Hal Tahduthu Mushkilat bayna al-Zawjayni, 2) al-Sahr Kharij al-Bayt, 3) al-Usrah Bayna al-Madi wa al-Hadir, 4) 'Aml al-Mar'ah, 5) Washiyatu Ab.

Bint Ismuha Tuffahah was written by Hanan al-Shaykh. Hanan is a leading journalist and writer in the modern Arab world. She was born in Lebanon in 1945. Her works are themed on the role of women in society, the relationship between men and women and marriage. She is also a writer in a women's magazine "al-hasna "' and "al-nahar" newspaper. The story of Bint ismuha Tuffahah in the textbook al-Kitab fi Ta'allum al-'Arabiyyah is a collection of stories from the book "wardatu al-Sahra"' published in Beirut by the publisher al-mu'assasah al-jami'iyyah li addirasat wa an-nashar".

The representation in the Bint ismuha Tuffahah text was found in the story of Bint Ismuha Tuffahah tells of a girl named Tuffahah who lives in an oasis (al-wahah) that tells about the problems of her life in finding her life partner. Tuffahah is described as a girl who is close to 40 years old and not married. Aside from Tuffahah, this story also describes the figure of mother and father of Tuffahah. The conflict in this story is the rejection of Tuffahah towards their culture towards marriage, which is putting a flag on the roof of the house (raf'u al-'alam 'ala sathi albayt). Circumstances in the Tuffahah environment are described by the compliance of the population with the prevailing culture. The culture includes the way a girl gets married and a rule that forbids a girl from leaving home except by covering her entire body and the requirement for a companion. 


\section{Arabi : Journal of Arabic Studies}

The relation in the text of Bint ismuha Tuffahah is the narrative relationship between speakers in this story. A brief dialogue took place between Tuffahah and his father when debating the reason for rejecting Tuffahah for "flag raising".

The identity in the text of Bint ismuha Tuffahah is that the author does not present himself in the text. All characters in the text are figurative figures. This can be understood as a form of social criticism of the culture of society. The criticism was conveyed by telling a story about a girl's inner debate. Although at first Tuffahah rejected the culture of his community, in the end, she was given in to that culture.

And the following is Tuffahah's point of view of marriage in her society's culture:

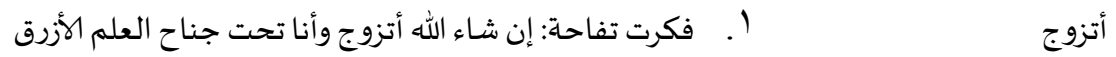

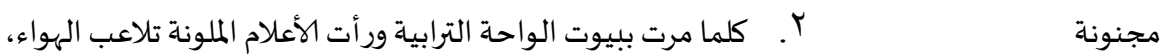

$$
\begin{aligned}
& \text { ضحكت في سرها وقالت: مجنونة، خفيفات العقل }
\end{aligned}
$$

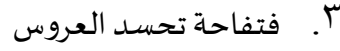

$$
\begin{aligned}
& \text { ع. ـنت أنها قد توصلت إلى الجواب هذه المرة: ما أبغى أترك الواحة } \\
& \text { 0 . أمسكت هذه المرة بالجواب الصحيح وكان بسيطا: ربما سيرفرف العلم لمدة } \\
& \text { شهور ولم يتقدم أحد. وأكون كالضيأن وكسلة التمر معروضة للبيع }
\end{aligned}
$$

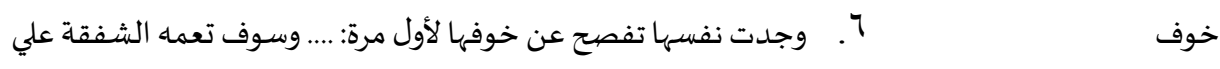

$$
\begin{aligned}
& \text { بأني بضاعة كاسدة }
\end{aligned}
$$

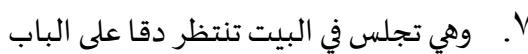

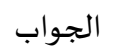

The following is a married culture in the Tuffahah's neighborhood. As well as, the rules applied to women in the environment:

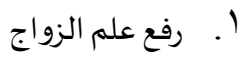

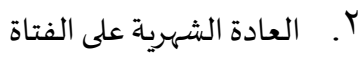

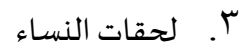

$$
\begin{aligned}
& \text { ع. وجدتها وأمها وخالاتها وعماتها وكل أنثى رأت النور في هذه الواحة تزوجت بطريقة العلم }
\end{aligned}
$$

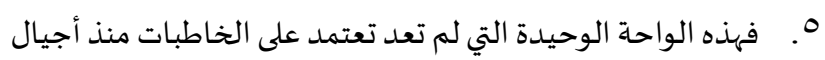

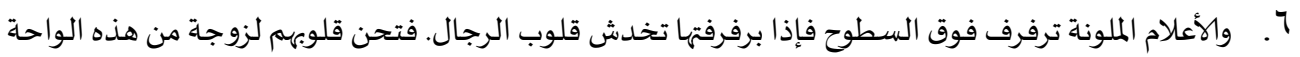

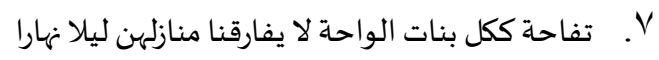

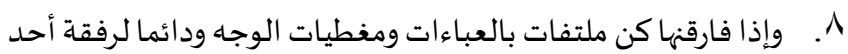

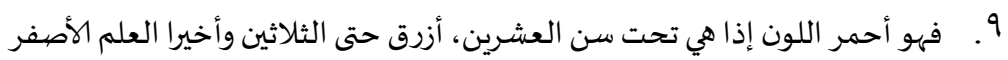

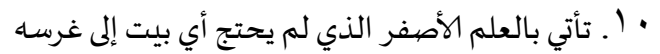

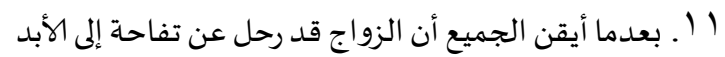

Based on the analysis of the text, it is known that early marriage is described by "raf' al'alam, which is the depiction that when a girl has entered her menstrual period, she must be married. In addition, the process of marriage in the text illustrated the necessity of the family to wait for the arrival of men to propose to the daughter. The process described in the text can cause problems for a girl who thought that she will be as goods to sell.

The second text is Zawaj al-Jayl al-Jadid. This story is a part of the book زوج مجرّب written by Muhsin Muhammad. The representation of this text is as follows: This story equates family discussion with the term Majlis al-usrah, whose members consist of all family members. This family member consists of a father, mother, daughter, mother-in-law (mother of the wife) and 
father-in-law (uncle of the father). This story illustrates that the leadership of the honor council is owned by the father, but in practice, the leadership is held by the mother-in-law. The author describes that marriage is not something emergency that needs to be discussed in the "al-usrah majlis". However, the main problem in this story is the debate between family members regarding the prospective spouse (husband) for the only daughter in the family. The family described in this story is an Egyptian family. And in the end, the father is the one who chose and decided a man to marry his daughter.

The following is some text that reflects a culture that prohibits or opposes a girl from choosing her own partner by her self. The text bellow represents that in matters of marriage should be considered the opinion of his daughter "نسأل البيت". But the mother-in-law affirmed with her

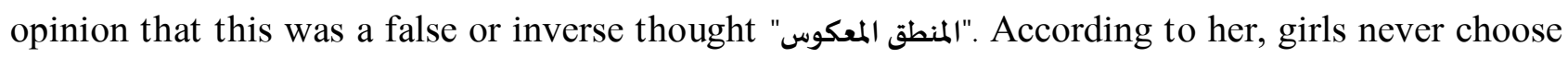
their partners. This is stated by "منذ متى تختار البيت الزوج". She then added that those who choose partners in a marriage are men, while girls only give approval or rejection.

$$
\begin{aligned}
& \text { قال الأب نسأل البنت } \\
& \text { قالت الحماة : لا يجب أن يكون لها رأي لالي لالي }
\end{aligned}
$$

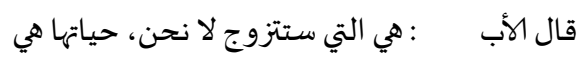

$$
\begin{aligned}
& \text { قالت الحماة :هذا هو المنطق المعكوس، منذ متى تختار البنت الزوج؟ هو الذي يختار وهي هي توافق أو ترفض }
\end{aligned}
$$

In addition, zawaj al-jayl al-jadid represents a mother-in-law's thoughts about marriage. That some of the conditions of marriage are equality. Education is also an important requirement in marriage especially if the girls have high education so that their prospective partners must have higher education.

$$
\begin{aligned}
& \text { قالت الحماة : إهها تحمل شهادة عالية وتدرس للماجستير. وهوراسب في الثانوية العامة. أين التكافؤ؟ أين الميول المشتركة؟ } \\
& \text { قالت الحماة : أنا لا أوافق أبدا على أن تتزوج حفيدتي من شادية التهاب لا يحمل مثل مؤهلاتها }
\end{aligned}
$$

The fourth text is Tatawwur Bani al-Usrah al-'Arabiyyah. This text was written by Zuhair Hatb in 1983 with some modification made by the author of al-Kitab fi Ta'allum al-'Arabiyyah. The text talks about social changes that occur in Arab society. Research on changes that occur in Arab society is more studied through the aspects of the community. This causes that change is considered to violate religious teachings (Ibti'ad al-Muslimin 'an ad-Din fi Hayatihim). These social changes have not been widely studied by social psychologists and anthropologists. If research from the aspects of social psychology and anthropology is expected to provide a deeper understanding to overcome or deal with changes that occur in the family of the Arab community. Some of the changes in roles in the family described in the text are as follows:

$$
\begin{aligned}
& \text { ( ) خرجت المرأة إلى سوق العمل }
\end{aligned}
$$

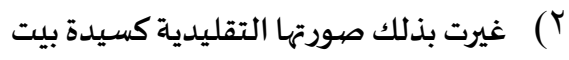

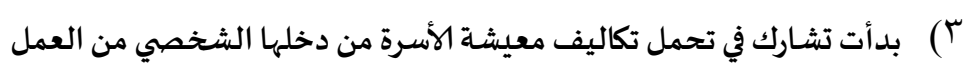

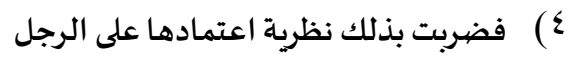

$$
\begin{aligned}
& \text { 0) المرأة بدأت تناقش زوجها في مختلف القضايا والمواضيع التي تؤثرعلى حياتهما المشتركة }
\end{aligned}
$$

This following text describes some cultural change in marriage:

$$
\begin{aligned}
& \text { ( ) أصبح الحب والعاطفة يشكلان الأساس الذي يقوم عليه الزواج بعدما ظلَّ لوقت طويل قائما على الترتيبات والرغبات } \\
& \text { العائلة } \\
& \text { (Y }
\end{aligned}
$$

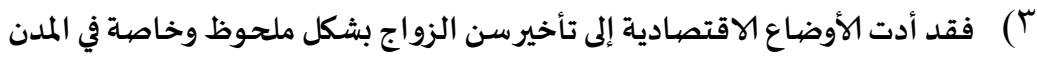

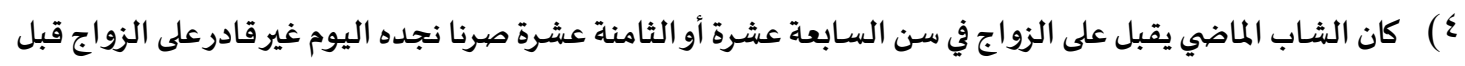

$$
\begin{aligned}
& \text { سن الرابعة والعشرين على الأقل النق }
\end{aligned}
$$




\section{Arabi : Journal of Arabic Studies}

ازدادت حالات الطلاق بين الأزواج وأصبحت الخلافات بينهم بيّنة ظاهرة للآخرين بعد أن كانت تبقى محصهورة في نطاق

ضيق.

The following text describes several possible factors that influence change in society: ( ) فقد لجأ معظم هذه الدراسات إلى الدين ليظهر خطأ التطور الذي تعرضت له الأسرة وكذلك ليبين أن ما أدى إلى هذا

$$
\text { كله هو ابتعاد المسلمين عن الدين في حياتهم. }
$$

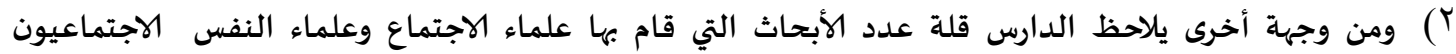

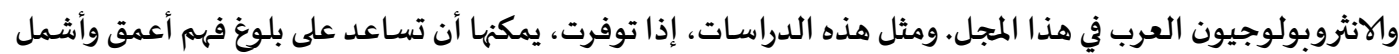

للتحولات التي تعرضت لها الأسرة العربية.

The fifth text is al-Jami 'Yufaddilunaha khadi'ah. This text is a part of the book "al-hubb fi 'asr al- 'awlamah" written by Muna Hilmi in 1999. This text describes the consequences of women who choose freedom. The freedom of women in this text is described as something bad and severe. The woman who chooses freedom in her life does not become the woman of choice for marriage by men.

The following text describes men's perceptions of women who have freedom in their lives:

$$
\begin{aligned}
& \text { (') الرجل المحب والمرأة الحرة أمران لا يجتمعان }
\end{aligned}
$$

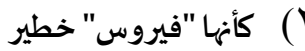

بَ) العجز الحقيقي للرجل ليس في نقصان القدرة الجنسية، ولكن في عدم القدرة على حب امرأة حرة التفكير والإرادة

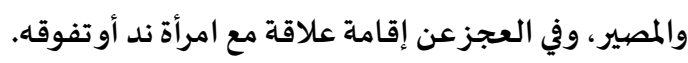

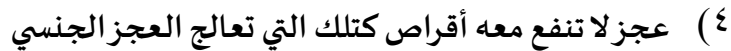

ه) حين يقرر أن يكمل نصف دينه يذهب إلى امرأة له علهيا الكلمة العليا سواء في الفلوس أو الرأي، ويستحسن بالطبع

خضوعها في الاثنين

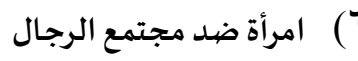

(V إن تعريف الرجل للزواج هو كيف يعثر على امرأة "مريحة" لا تثير تساؤلات أو مشاكل، امرأة مغمضة العينين، ومغمضة

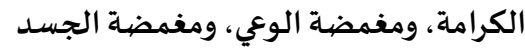

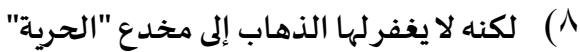

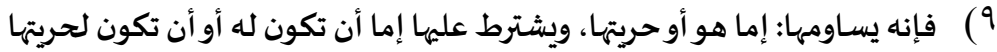

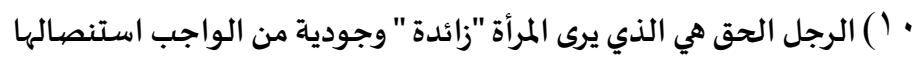

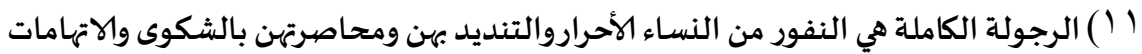

The analysis in the al-'Arabiyyah bayna Yadaik found that some texts in al-'Arabiyyah bayna Yadaik are related to the theme of marriage. The first text "هل تحدث مشكلات بين الزوجين". This text states that problems in marriage are caused by differences between males' and females' personality. The problem is also stated in the dialogue "السهر خارج البيث". Marriage problems occur in the family because the husband demands his wife to pay attention to him. The main theme is reaffirmed in the text of fahmu al-masmu 'the second part of chapter 3 of the third volume, namely:

$$
\begin{aligned}
& \text { المشكلات الزوجية } \\
& \text { ا كان الأب في المجتمعات القديمة يرعى زوجته وأولاده. وكانت الأم تدير المنزل، وتربي الأطفال. كان الأب في تلك المجتمعات، } \\
& \text { هو وحده الذي يتخذ القرارات، فهو رب الأسرة. أما في العصر الحديث، فأصبح الأب والأم يشتركان معا في اتخاذ القرارات، } \\
& \text { لأن المشكلات كثرت وزادت تعقيدا. وأصبح الأولاد يشاركون في اتخاذ القرارات. } \\
& \text { r ل لكل أسرة مشكلات، وقد تحدث المشكلات، لاختلاف أفراد الأسرة في السن، والأفكار، والاهتمامات، وبسبب العيش في } \\
& \text { مكان واحد، وما يؤدي إليه من احتكاك. ولا شك أنّ الأب والأم قادران على حل كثير من المشكلات، إذا لجآ إلى الحوار } \\
& \text { وتحليا بالصبر. }
\end{aligned}
$$




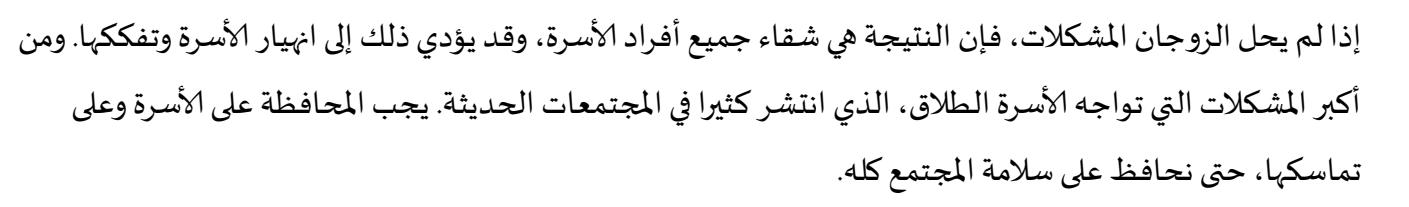

The issue of marriage is also illustrated in the text of Wasiyyatu Abb. This text confirms that marriage is a big responsibility and requires effort and hard work to maintain it. This text reinforces the view that a wife has a duty to maintain the integrity of her marriage.

The divorce case contained in wasiyyatu Abb describes that divorce occurs because some of the women consider marriage as recreation or entertainment. The description is written as follows:

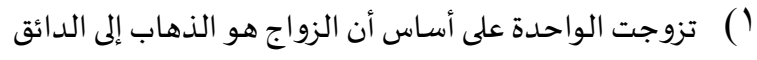

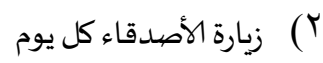

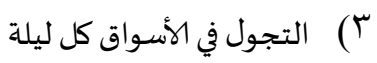

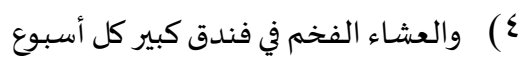

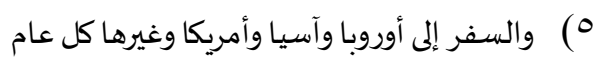

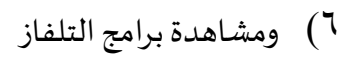

$$
\begin{aligned}
& \text { ( ) وسماع الإذاعات }
\end{aligned}
$$

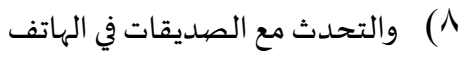

$$
\begin{aligned}
& \text { 9) ولبس أفضل الملابس وأحدثها وكذلك لبس أفضل أنوان النواع الحلي بين الحين والحين } \\
& \text { • ( ) والسهر في النوادي النسائية } \\
& \text { (1) (1) (1) والجلسات العهرئلية } \\
& \text { r T (1) ) وركوب أجمل السيارات }
\end{aligned}
$$

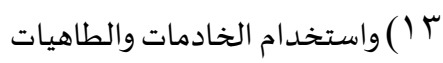

$$
\begin{aligned}
& \text { ـ ا ) والسكن في أجمل البيوت }
\end{aligned}
$$

In addition, in the text "Fahm al-masmu" in the fourth volume in al-'Aarabiyyah bayna Yadaik there is a text that talks about "asbab al-khilafat az-zawjiyyah". The text represents that some reasons for differences or problems in marriage are as follows: choosing a partner who is not right and not in accordance with religious provisions. In addition, the reason for divorce is because the wife does not understand the financial condition of her partner and forces him with many requests.

$$
\text { • • بعضء الاختيار أو بمعنى آخر، عدم مراعاة الضوابط الشرعية التي وردت في اختيار المرأة أو في اختيار الرجل }
$$

The texts of al-Usrah bayna al-madhi wal al-hadir in al-'Arabiyyah bayna Yadaik describe the changes in the family. There is a lot of information about the wife's activities connoted as a mistake. The mistake referred to in this text is that women do not have time to care for their children and homes. The emphasis of this text is on the last paragraph describing social change for women. In the past, a woman did not work outside the home. Women only leave the house on urgent matters. Whereas women currently leave home in the morning and return home in the afternoon. This text describes that women's duties are to take care of household chores, such as cleaning the house, preparing food and taking care of their families. In addition, women's existences seemed to be limited to the problems of the household and children.

The text that describes women in the past

$$
\text { لا تخرج من بيتها إلا عند الضرورة }
$$

The text that describes women nowadays

$$
\text { تغادر الزوجة بيتها في الصباح ولا ترجع إليه إلا في المساء }
$$




\section{Arabi : Journal of Arabic Studies}

The text that describes women's obligations

$$
\begin{aligned}
& \text {... لا تقوم بعمل البيت من نظافة وإعداد للطعام }
\end{aligned}
$$

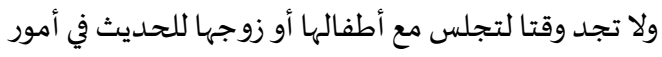

$$
\begin{aligned}
& \text { الأولادوالبيت. }
\end{aligned}
$$

The text 'aml al-mar'ah in al-'Arabiyyah bayna yadaik begins with the question" do women work outside the home or not? ". The problem was answered by giving three views from three groups, namely first: Yes, women must (يجب) work outside the home like men. Second: it is not true that women work outside the home. Third: women work outside the home, but on condition.

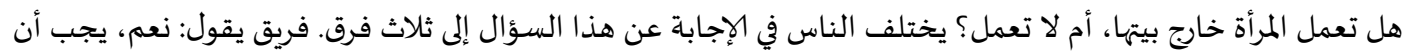

$$
\begin{aligned}
& \text { تعمل المرأة خارج بيتها، مثل الرجل. وفريق آخر يقول: لا يصح أن تعمل المرأة خارج بيتها. وفريق ثالث يقول: تعمل المرأة خارج } \\
& \text { بيتها ولكن بشرط. } \\
& \text { يقول الفريق الأول: إنّ المرأة نصف المجتمع، ولا يصيّ أن تجلس في بيتها. تغسل الملابس، وتعدّ الطعام، وتنظف البيت، وتربي }
\end{aligned}
$$

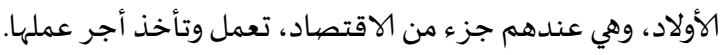

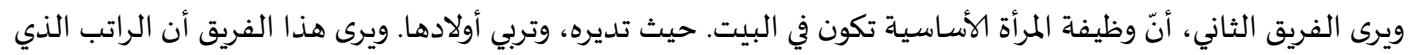

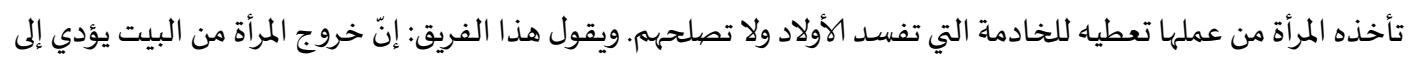

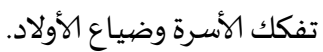

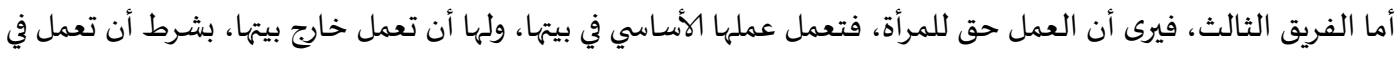

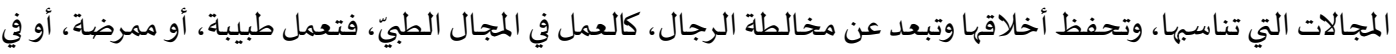

$$
\begin{aligned}
& \text { المجال التعليميّ، فتعمل معلمة أو مربية أو غير ذلك في مجتمع نافيات نسائي. }
\end{aligned}
$$

This text describes the views of three community groups about career women or women who work outside the home. The first group states that women must work outside the home because women are part of the community. The second group states that women are not allowed to work outside the home. While the third group stated that women could work outside the home, but with conditions. The views of the third group become views emphasized in the textbook al-'Arabiyyah bayna Yadaik. This can be seen from the consistency of textbooks in providing professional examples for women.

In addition to cultural elements regarding women and their position in marriage and society, the two textbooks also contain other cultural elements. The cultural material section contained in the al-Kitab fi Ta'allum al-'Arabiyyah is a complement to the ammiyah video and dialogue section. It aims to provide flexibility for teachers in providing explanations about the culture. The teacher can choose the parts that are considered important. Teachers can start using the DVD in the culture section, then provide questions and discussions. The steps recommended in the explanation of culture in the al-Kitab fi Ta'allum al-'Arabiyyah textbook are 1) before the instructor explains the topic of culture, students are asked to watch the video. Then the teacher asks what the student understands; 2) the students watch as many videos as needed, then discuss and explain the expressions contained in the video; 3) the students watch the video for the last time. After that, students practice the phrases that have been discussed in accordance with the situation and creativity of students. While the culture contained in al-'Arabiyyah bayna Yadaik is Islamic Arabic culture and Universal Culture that does not contradict Islamic values. This can be seen from some part in the textbook as following: 

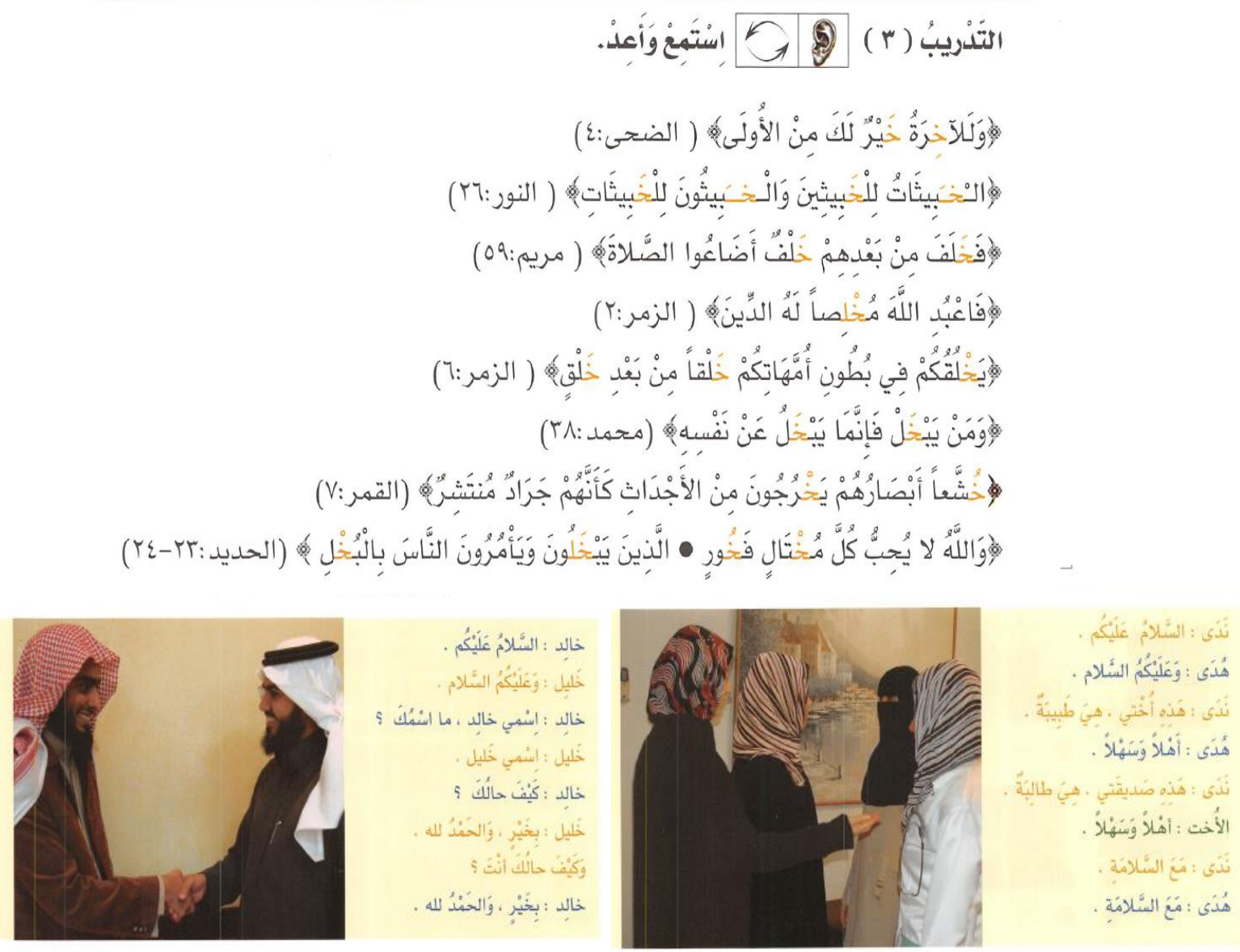

The socio-cultural aspect based on the findings of the linguistic analysis above is the problem of early marriage and arranged marriages between relatives. The culture of early marriage in Arab society can be caused by understanding the religious and cultural community. Akram Alsaidi (2015) explained that early marriages occur because of wrong religious understanding. The main factor causing early marriage is poverty. There is not a single verse that specifically states about the age that can get married.

Hoda Rashad, Magued Osman, and Farzaneh Roudi Fahimi (2005) stated that early marriage to Arab society had diminished. This is influenced by the economic situation of Arab society that developed from an agrarian system. The agrarian system is a factor that causes early marriage. The younger generation of Arab society has a better education than the previous generation, therefore many young Arab women prefer to become career women. Changes in trends in marriage in Arab society can also be seen from the age of women at marriage. Arab women today prefer to marry at the age of 20-30 years.

In addition, Hoda Rashad, Magued Osman, and Farzaneh Roudi Fahimi (2005) confirmed the impact of early marriage. An early marriage to Arab society is driven by traditional values of "female virginity" and respect for families. Early marriage is generally associated with early birth and high fertility. This can pose health risks for women and their children. Early marriage can cause disease transmission due to lack of knowledge about contraception and reproductive health. In addition, the age gap between the husband and wife can also increase the risk for women in terms of their health. In addition, early marriage can also cause school dropouts. This causes women to not be able to get out of the cycle of poverty, high reproductive rates, and poor health.

The form of marriage that characterizes Arab society is a marriage between relatives, especially marriage between cousins (consanguinity). Hoda Rashad, Magued Osman, and Farzaneh Roudi Fahimi (2005) explained that marriages between relatives were common in Sudan, Libya, and Saudi Arabia. Marriage between relatives occurs in the range of 40 to 50 percent of married women aged 15 to 49 years, they are married to their first cousin. Not all marriages between 


\section{Arabi : Journal of Arabic Studies}

relatives are arranged or forced marriages. Some marriages between relatives occur because of the desire of a married couple. However, the risk of marriage between close relatives is endangering the health of their children, as is a marriage between families with a history of genetic diseases.

Mohamed Knidiri [26] mentioned that Morocco enacted a new Family Law that was enacted in 2004. It established equality between the sexes by regulating a number of fundamental questions: shared family responsibilities, guardianship of women, age of marriage; (almost entirely) the prohibition of polygamy; recognition of marriages contracted abroad; denial; divorce; child custody; children born out of wedlock, separation of assets.

In addition, the analysis of aspects of the practice of discourse or meso level in this analysis is the emergence of these texts in the textbooks al-'Arabiyyah bayna Yadaik and al-Kitab fi Ta'allum al-'Arabiyyah influenced by the socio-cultural background of the authors of both books the text and also influenced by the learning objectives carried by the author and publisher of textbooks.

\section{Conclusion}

From the discussion before, this study concludes that Arabic textbook al-Kitab fi Ta'allum al-'Arabiyyah and al-'Arabiyyah bayna Yadaik describe women and marriage in a multiperspective way. The textbook al-Kitab fi Ta'allum al-Arabiyyah discusses the issue of marriage by criticizing the form of forced marriage, a marriage which is closely related to culture. In addition, early marriage is also discussed in this textbook as a cause of divorce in marriage. Forced marriages as depicted in this textbook are related to the marriage and early marriage system. The culture of Arab society to marry off their daughters with relatives is also a problem discussed in the textbooks of al-Kitab fi Ta'allum al-'Arabiyyah. Marriage is considered as a solution to avoid negative "labels" of families who have daughters. The second textbook, al-'Arabiyyah bayna Yadaik describes women and marriage by providing a point of view of women's role when becoming wives. Some texts describe the problems that occur in marriage and the perspective of women working outside the home. That multi-perspective need to be discussed in Arabic language teaching to provide an understanding of the Arabic culture regarding women's issues and marriage based on community culture

An understanding of culture in the speech community and an understanding of cultural differences need to be conveyed in learning Arabic. In addition, cultural comparisons need to be discussed in learning Arabic. That is because every community has different cultures and cultural norms. Students need to understand Arabic culture, Islamic culture, and Indonesian culture. The urgency to learn Arabic with cultural understanding lies in the aspect of the use of the language. Because anyone who studies the Arabic language without understanding its culture, they cannot interact with Arab society. Or at least they cannot deal with cultural situations that he does not understand. So that it can cause a negative stigma towards Arab culture that is different from their culture. Therefore, cultural understanding needs to be taught in order to be able to communicate and interact in Arab society. In addition, the use of these two textbooks needs to be given an understanding and critical reading of the text. Both textbooks provide effectiveness in learning outcomes based on their respective portions. Al-'Arabiyyah bayna Yadaik is considered more suitable for use in learning basic language skills, while al-Kitab fi Ta'allum al-'Arabiyyah can be used as additional references because it contains more diverse material themes.[]

\section{References}

Abdallah, Mahmoud. 2006. "Arabic Immersion and Summer Programs in the United States", Handbook for Arabic Language Teaching Professionals in the $21^{\text {st }}$ Century. Ed Kassem M. Wahba, Zeinab A. Taha dan Liz England. New Jersey: Lawrence Erlbaum Associates Publisher.

Vol. 5 No. 1 | 22-24

Copyright @ 2020 | ARABI | p-ISSN 2548-6616 | e-ISSN 2548-6624 
Abu Syairi, Khairi. 2013. "Pengembangan Bahan Ajar bahasa Arab", Dinamika Ilmu : Jurnal Pendidikan, Vol. 13, No. 1.

Alsaidi, Akram. 2015. "What Drives Child Marriage in the Arab World and How the World is Combating the Problem", Law School Student Scholarship, Paper 775. http://scholarship.shu.edu/student_scholarship/775

Aoumer, Hayat. 2014. "Gender Representation in Three School Textbooks: a Feminist Critical Discourse Analysis", IMPACT: International Journal of Research in Humanities, Arts and Literature, Vol. 2, No. 2.

Azisah, Siti. 2017. "Gender Representation in English Textbooks of 2013 Curriculum in an Islamic Junior High School in South Sulawesi Indonesia", Proceeding: International Conference on Natural and Social Sciences.

Baghdadi, Mitra., \& Ali Rezaei. 2015.“Gender Representation in English and Arabic Foreign Language Textbooks in Iran: A Comparative Approach”, Journal of International Women's Studies, Vol. 16, No.3.

Bateman, Blair., \& Marilena Mattos. 2018. "an Analysis of the Cultural Content of Six Portugese Textbooks", http://www.researchgate.net/publication/241082164_An_Analysis_of_the_ Cultural_Content_of_Six_Portuguese_Textbooks, accessed December, 2018.

Darma, Yoce Aliah. 2009. Analisis Wacana Kritis. Bandung: CV.Yrama Widya.

Eriyanto. 2008. Analisis Wacana: Pengantar Analisis Teks Media. Yogyakarta: LkiS.

Fairclough, Norman. 1992. Critical Language Awareness. New York: Routledge.

Fairclough, Norman. 1995. Critical Discourse Analysis: Paper in the Critical Study of Language. London: Longman.

Fakih, Mansour. 2013. Analisis Gender dan Transformasi Sosial. Yogyakarta: Pustaka Pelajar.

Hasmam, Aisah., \& Nik Mohd Rahimi. 2010. "Types of Text in Books for Learning Arabic as a Second Language: a Document Analysis", Procedia Social and Behavioral Science, Vol. 7 (C).

Husni, Arman. 2010. "Pengembangan Bahan Ajar Bahasa Arab untuk Pemula”, al-Ittijah, Vol. 2, No. 1.

Knidiri, Mohamed. 2009. "Women in Arab Societies the Case of Morocco", in Ambrosi L. et.at (ed), Women status in the Mediterranean: their rights and sustainable development. Bari: CIHEAM. http://om.ciheam.org/om/pdf/a87/00801048.pdf

Liddicoat, Anthony J., \& Kerry Taylor-Leech. 2015. "Multilingual education: the role of language ideologies and attitudes", Current Issues in Language Planning, Vol. 16, No. 1-2.

Lips, Hilary M. 2008. Sex and Gender: an Introduction. Illinois: Waveland Press.

Nugroho, Riant. 2008. Gender dan Strategi Pengarus-utamaannya di Indonesia. Yogyakarta: Pustaka Pelajar.

Olajide, Stephen Billy. 2010. "A Critical Assessment of the Cultural Content of Two Primary English Textbooks Used in Nigeria", Journal of Language Teaching and Research, Vol. 1, No. 5.

Orr, Make. 2014. "Ideology for second Language Teachers", Arab World English Journal, Vol. 5, No. 4. 
Arabi : Journal of Arabic Studies

Ottom, Kamel Ali Suleiman. 2014. "The Image of Women in the Arabic Language Textbook for the Primary Second Grade in Jordan", European Scientific Journal, Vol. 10, No.7.

Rashad, Hoda., Magued Osman, \& Farzaneh Roudi Fahimi. 2005. "Marriage in the Arab World", Population Reference Bureau, https://assets.prb.org/pdf05/MarriageInArabWorld_Eng.pdf

Subhan, Zaitunah. Al-Qur'an dan Perempuan: Menuju Kesetaraan Gender dalam Penafsiran. Jakarta: Kencana.

Tajima, Misako. 2010. "Ideological messages embedded in an EFL textbook", JALT Conference Proceeding.

Tierney, Helen. 1999. Women's studies Encyclopedia. Wesport: Greenwood Press.

Tollefson, James W., \& Mai Yamagami. 2013. "Language Ideology in a Language Classroom", The Encyclopedia of Applied Linguistics, Edited by Carol A. Chapelle. Blackwell Publishing.

Umar, Nasaruddin. 2001. Argumen Kesetaraan Gender Perpektif Alqur'an. Jakarta: Paramadina. 